\title{
Confronting the 'sustainable-growth' fallacy impeding the realization of sustainable development and sustainable cities
}

\author{
G. Zovanyi \\ Department of Urban Planning, Public \& Health Administration, \\ Eastern Washington University, USA
}

\begin{abstract}
The Brundtland Commission Report of 1987 laid out the case for ongoing economic growth as an essential prerequisite for sustainable development. This paper identifies reasoning utilized in that Report to support the idea of 'sustainable economic growth'. The paper then argues that this economic progrowth bias has continued to represent the dominant, mainstream viewpoint within the sustainable-development movement. In a similar vein, the paper suggests widespread support for the idea of 'smart growth' as a form of 'sustainable urban growth' capable of advancing the end of sustainable cities. The purpose of the paper is to make the case for the intrinsically unsustainable nature of economic and urban growth. Included among the results of the paper are references to publications from the 1990s and the current decade revealing mounting evidence of existent ecological limits to growth. As its central conclusion the paper argues that continued allegiance to the idea of 'sustainable growth' constitutes a major impediment to realizing the ends of sustainable development and sustainable cities.
\end{abstract}

Keywords: 'sustainable growth', intrinsically unsustainable growth, ecological limits to growth, sustainable development, sustainable cities.

\section{Introduction}

It has been noted that the concept of sustainable development achieved worldwide recognition and credibility with publication of the Brundtland Commission Report in 1987 [1]. Recently other observers have cited works to support the claim that the Report set the standard and became the point of 
reference for every debate on sustainable development [2]. The 1987 Report ended up influencing the nature of a nascent sustainable-development movement in two key ways. First, it provided what would come to be the most widely cited meaning for the term sustainable development; defining it as development that meets the needs of the present generation without compromising the ability of future generations to meet their needs [3]. Second, it influenced the emerging sustainable-development movement by laying out the case for the legitimacy of ongoing economic growth to meet present and future needs. This view of sustainable development as a system for needs satisfaction that can persist forever [4] produced support for the idea of 'sustainable economic growth' within the Brundtland Report. This paper presents reasoning used in the Report to support the idea of 'sustainable economic growth' and then argues that support for this idea has come to represent the norm within the sustainabledevelopment movement.

This paper also characterizes the nature of the sustainable-cities movement that has emerged from within the broader sustainable-development movement. That characterization suggests the initial concerns of the former movement were largely silent on the matter of an explicit growth orientation, but that overlaps with a 'smart-growth' movement that emerged in the latter 1990s yielded a decidedly pro-growth orientation supportive of the idea of 'sustainable urban growth'. The ideas of 'sustainable economic growth' and 'sustainable urban growth' are subsequently portrayed as being fatally flawed and wholly irrelevant in light of mounting evidence that global ecological limits to growth have already been surpassed. Finally, this paper argues that continued allegiance to the idea of 'sustainable growth' impedes any meaningful advances in realizing either sustainable development or sustainable cities.

\section{Support for the idea of 'sustainable economic growth'}

Support for the idea of 'sustainable economic growth' within the sustainabledevelopment movement may largely be attributed to the ongoing influence of the 1987 Brundtland Commission Report. That Report strongly endorsed the need for ongoing economic growth as an essential prerequisite for sustainable development, and presented reasoning in support of the possibility of 'sustainable economic growth' that continues to dominate sustainabledevelopment thinking during the current era. The nature of that reasoning and its demonstrated staying power are briefly investigated in this paper as a backdrop to a concluding argument that the idea of 'sustainable economic growth' is actually counterproductive to realizing sustainable development.

\subsection{Brundtland Report's endorsement of 'sustainable economic growth'}

As noted above, the Commission's Report presented a view of sustainable development framed in terms of an ability to satisfy human needs into the foreseeable future. With the Commission's focus on meeting human needs in the present and future, it called for a new era of rapid economic growth in both developed and developing countries to relieve poverty across the globe. The 
Commission clearly identified the necessary development path for meeting those needs in terms of an expanded capability for goods and services provided by industry. This commitment to economic growth fuelled by industrial expansion was expressed in the Report by references to industry being an indispensable motor of growth. The perceived role of industry in satisfying one of the prerequisites of sustainable development was accentuated when the Commission extended the definition of sustainable development beyond meeting basic needs to the realm of encompassing aspirations. In extending the entitlement beyond basic human needs, the Commission opened the door to a necessary explosion of global industrial growth to meet both the needs and aspirations of humans over the long term.

The Brundtland Commission left no doubt as to its expectation of both needs and aspirations being met by material goods produced by manufacturing industries. In light of projected population increases, the Commission's Report called for a five- to tenfold increase in manufacturing output to raise developingworld consumption of manufacturing goods to industrial world levels by the time population growth rates level off sometime during the 21 st century. To further that end, the Report called for a sustained economic growth rate of 5 to 6 percent in developing countries, and an ongoing growth rate of 3 to 4 percent in industrial countries. The continued growth advocated for industrial countries was justified under the reasoning that an interdependent world economy made prospects for growth in the developing world dependent on continued growth in industrial nations. In the end, the Report argued the case for a rapidly growing world economy as a necessity if large parts of the developing world were to avert economic, social, and environmental catastrophes. Ultimately, this line of reasoning led the Commission to make the case for the possibility of 'long-term sustainable growth'.

The Brundtland Commission made its case for the possibility of 'sustainable industrial growth' and 'sustainable economic growth' on the basis of a few key arguments: an achievable compatibility between economic growth and ecological sustainability; possible dematerialization and efficiency gains; prospects for resource substitution; technological optimism; and changes in production and consumption patterns. These arguments in support of the idea of 'sustainable economic growth' have demonstrated tremendous staying power since the publication of the Brundtland Report.

\section{2 'Sustainable economic growth' as a mainstream viewpoint}

More than twenty years have passed since publication of the Brundtland Commission Report, but the perspectives on sustainable development laid out in that document have continued to dominate present formulations of sustainable development. The Commission introduced the idea that realizing sustainable development would require paying equal attention to the economic, ecological, and social dimensions of sustainability. Sustainable-development literature abounds with references as to the need to integrate, synthesize, harmonize, or balance these three dimensions of sustainable development [5-7]. However, despite the appeal of a three-dimensional view of sustainable development, it has 
been claimed that many applications of the concept prioritize economic considerations over ecological and social concerns, resulting in sustainable development remaining a predominantly economic concept [7]. Others support this viewpoint by noting the usual dominance of economic concerns under sustainable development [8], the prominence within sustainable-development literature of views that give critical importance to economic advances in achieving sustainability [9], and the role of political reality in giving primacy to the economy in sustainable-development programs [10]. Such views of sustainable development have concentrated on the development component of the concept and interpreted it as meaning growth as defined in standard neoclassical economic terms [10].

Modern economic theory considers individual utility maximization as the reference for collective behaviour (i.e., what is good for the individual is good for society) and puts individual maximization of income and wealth at the centre of the analysis [11]. From this perspective neoclassical economics sees infinite economic growth and prosperity as the dominant imperative [12]. Under this reasoning, economic growth, defined by increased production and consumption, is considered the main priority and seen as the key to humanity's well-being [13]. This leads to the conclusion that in almost all respects the main organizing principle of sustainable development is economic growth [14]. This in turn leads to an acknowledged obsession with economic growth and the belief that it can continue indefinitely [7], and a view of sustainable development that sees its primary objective as that of achieving the highest sustainable economic growth possible [5]. Prospects for such 'sustainable economic growth' end up being based on the same arguments utilized in the 1987 Brundtland Commission Report. Under widespread acceptance of those arguments the idea of 'sustainable economic growth' has come to represent the dominant, mainstream viewpoint within the sustainable-development movement.

\section{Support for the idea of 'sustainable urban growth'}

Over time, a sustainable-cities movement has emerged from within the broader sustainable-development movement. While the sustainable-cities movement has championed a number of distinct causes, it has been largely silent on the matter of an explicit growth orientation. However, its recent affiliation with a 'smartgrowth' movement that emerged in the latter 1990s has yielded a decidedly progrowth orientation supportive of the idea of 'sustainable urban growth'.

\subsection{The growth orientation of the sustainable-cities movement}

The sustainable-cities movement did not abandon the prior emphases of those within the broader sustainable-development movement on realizing ecoefficiency gains in the use of materials and energy, reducing pollution loads, employing appropriate technologies, and changing production and consumption patterns. However, the sustainable-cities movement introduced a new emphasis on creating living configurations that support adoption of sustainable life-styles [15]. With a focus on how urban settings might advance sustainability, 
sustainable-cities advocates advanced a broad array of initiatives, including programs to advance sustainable economic development, sustainable energy and materials use, sustainable urban ecology, sustainable urban design, sustainable architecture and building practices, and sustainable transportation [16]. These proposals have largely tended to abstain from offering specific stances on urban growth. While the broader sustainable-development movement clearly staked out a position on the possibility of 'sustainable economic growth', spokespersons for the sustainable-cities movement have not felt compelled to defend the possibility of 'sustainable urban growth'. If any position on urban growth is to be inferred from sustainable-cities literature, it has been the implied stance that ongoing urban growth may be sustained if it occurs in terms of new highly efficient urban configurations supportive of sustainable living. In the United States this implied stance on urban growth has recently shifted to a more explicit defence of 'sustainable urban growth' as proponents of sustainable cities have developed affiliations with members of a 'smart-growth' movement.

\section{2 'Sustainable urban growth' within the 'smart-growth' movement}

A growth-management movement emerged in the United States during the late 1960 s and early 1970 s in response to growth-induced problems. That movement demonstrated a strong growth-accommodation bias [17]. The growthmanagement movement espoused a 'balanced-growth' argument [18], asserting that growth and environmental protection represent equally legitimate objectives, and that a balance could be achieved between these ends without compromising either. Embedded in this reasoning was the belief that growth could continue to be accommodated if it were properly planned and its negative effects adequately mitigated. Some proponents of this mainstream approach to growth management extended their arguments to suggest prospects for 'sustainable growth' [19, 20].

By the mid-1990s the American growth-management movement had expanded its realm of considerations under the banner of 'smart growth' to encompass a number of new considerations. Those new considerations have been encompassed under a short list of the five major tenets of 'smart growth': growth containment in compact settlements; protection of the environment, resource lands, and open space; multi-modal transportation systems; mixed-use development; and collaborative planning and decision making [21]. Among these five tenets, the central goal of the 'smart-growth' movement has been that of ending the lowdensity development of sprawl. In addition to adopting the earlier anti-sprawl bias of the growth-management movement, the 'smart-growth' movement also carried forward the pro-growth bias of earlier growth-management initiatives. Researchers have concluded the 'smart-growth' movement is, in fact, much more pro-growth than earlier growth-management efforts [22]. Proponents of this perspective see endless opportunities for ongoing growth if it occurs in the form of 'smart growth'. Under this line of reasoning, 'smart-growth' advocates readily envision options for 'sustainable urban growth' under an array of 'smart-growth' initiatives. To the extent that a growing number of American cities are simultaneously undertaking both 'smart-growth' and 'sustainable-cities' initiatives, the quest for advancing the end of sustainable communities in the United States has increasingly come under 
the influence of 'smart-growth' reasoning. This interest in 'smart growth' within the sustainable-cities movement has produced an increasingly explicit defence of the idea of 'sustainable urban growth' among proponents of sustainable-cities initiatives. In the remaining sections of this paper it will be argued that the idea of 'sustainable urban growth' is just as counterproductive to realizing sustainable cities as the idea of 'sustainable economic growth' is to advancing the end of sustainable development.

\section{The unsustainable nature of economic and urban growth}

Suggestions that economic and urban growth can somehow be transformed into sustainable increases ignore Herman Daly's 'First Law of Sustainability', the truism that it is development that can have the attribute of sustainability, not growth [23]. The fallacy of assuming material increases might somehow represent sustainable behaviour also ignores the incontrovertible axiom that infinite growth is impossible in a finite system presented in the 1972 book Limits to Growth [24]. Additional support for the assertion that growth in economic and urban terms is intrinsically unsustainable derives from the nature of the definition for sustainability, i.e., behaviour capable of being sustained or continued indefinitely.

Ultimately, the magnitudes capable of being generated by ongoing exponential growth clearly illustrate the unsustainable nature of material increases. Take, for example, the mathematical calculation revealing that if our species had started with just two people at the time of the earliest agricultural practices some 10,000 years ago, and increased by $1 \%$ per year, today humanity would be a solid ball of flesh with a diameter greater than the size of our solar system and a radius expanding outward faster than the speed of light [25]. Clearly, even the seemingly innocuous demographic growth rate of $1 \%$ is unsustainable over the long term because of the immense numbers associated with ongoing doublings. Economic and urban growth sustained over the long term produces similarly absurd numbers.

Annual economic growth rates of greater than $10 \%$ recorded in China over the past decade translate into a doubling time of only 7 years. Ten such doublings over the course of 70 years would yield an economy one thousand times its current size, and another ten doublings during the subsequent 70 years would expand China's economy to one million times its present size. Past exponential economic growth has already produced a global economy where economic expansion in the year 2000 exceeded that during the entire $19^{\text {th }}$ century [26]. Such numbers clearly portend insurmountable challenges in attempting to maintain such ongoing doublings through 'dematerialization' and 'ecoefficiency' gains. If an economy were, for example, to cut its current material and energy needs in half, any subsequent doubling in the size of that economy would nullify those gains.

The challenges are just as daunting with respect to ongoing urban growth. The world's urban population reached 2.9 billion in 2000 and is expected to rise to 5 billion by 2030. With the world's cities growing in total by more than 60 million residents each year, dramatic changes are being recorded. For example, 
the number of 'megacities' of over 8 million residents increased from just 2 in 1950 to 21 in 1990, and is projected to jump to 33 by 2015 [27]. In the United States, the 33 million people added during the decade of the 1990s translate into the equivalent of 33 cities of 100,000 every 12 months. These increases are every bit as unsustainable as the above noted economic increases. Hopes of being able to sustain such growth via more efficient settlement patterns also succumb to the pernicious effects of ongoing growth. For example, if an urban centre were to realize land-use efficiencies by cutting the land consumption of its next 1,000 residents in half, that land savings would be negated by the next 1,000 residents. Ongoing material increases represent unsustainable behaviour in that they cannot be sustained or continued indefinitely. No amount of wishful thinking or verbal gymnastics will serve to transform such growth into sustainable behaviour. The unsustainable nature of continued growth in economic and urban terms is increasingly being revealed by examples of existent ecological limits to growth that suggest realizing a state of no growth in material terms represents an essential prerequisite for realizing sustainable development and sustainable cities.

\section{Existent ecological limits to growth}

Evidence of existent ecological limits to growth has been mounting since the early 1990s. In 1991 the Ecological Society of America declared the existing scale of the human enterprise was threatening the sustainability of Earth's lifesupport systems [28]. During the early 1990s a noted ecologist warned that under current and accelerating trends fully $50 \%$ of the remaining species on the planet could be eliminated by 2050 [29]. By 1997 research on per capita ecological footprints revealed an average ecological footprint of some 2.31 hectares, whereas the planet was found to contain only about 1.7 hectares of ecologically productive space per capita [30]. These calculations suggest the ecological footprint of humanity had already exceeded the planet's ecological capacity to sustain the human enterprise prior to 2000, and that the existent scale of the human enterprise was therefore living off the capital base of renewable resources rather than from their sustainable annual incomes. In 2002 an international team of ecologists, economists, and conservation biologists published a study indicating that nearly all ecosystems on the planet are shrinking in response to expanding human demands on the natural world [31]. In 2004 the World Wildlife Fund issued a fifth Living Planet Report with its index of average trends in populations of terrestrial, freshwater, and marine species and noted that the index had declined by about 40\% from 1997 to 2000 [32]. In 2005 a four-year assessment of the state of global ecosystems reported in a study titled Millennium Ecosystem Assessment that some 60\% of the ecosystem services that support life on Earth are being degraded or used unsustainably [33]. In 2007 the Intergovernmental Panel on Climate Change released its fourth assessment report, announcing the 'unequivocal' nature of climate change, and stating it was more than $90 \%$ likely to be attributable to human causes [34]. This implied the existing scale of the human enterprise was already impacting the ability of the global ecosystem to carry out its essential life-support services of maintaining a 
benign mix of gases essential to life as we know it and climate control in the form of moderation of the weather. Taken together the above findings confirm existent ecological limits to further growth of the human enterprise.

\section{The no-growth prerequisite for realizing sustainability}

If even the present scale of the human enterprise is dismantling the ecosystems upon which all life is utterly dependent, then it is time to concede the existence of current ecological limits to growth. These existent ecological limits to growth must quickly come to be understood as demanding the acceptance of a speedy transition to a state of no growth in material terms as an essential prerequisite for realizing truly sustainable development and sustainable cities. For this transition to occur, mainstream thinking within the sustainable-development and sustainable-cities movements will have to abandon its current endorsement of 'sustainable economic growth' and 'sustainable urban growth'. The idea of 'sustainable growth' must be recognized as being worse than an 'oxymoron' and elevated to the status of a 'moronic oxymoron'. Growth in the material terms of economic and urban increases needs to be rejected on the grounds it does not satisfy the definitional requirement of behaviour capable of being maintained or continued indefinitely, the absurd numbers currently being generated under exponential economic and urban increases; and based on existent ecological limits to further growth. Given what ecologists are now telling us about the effects of ongoing growth on other species and ecosystems, and the realization that these effects are incongruous with ecological sustainability, it seems that we have no option but to accept the current reality of present limits to any further economic and urban growth. That acceptance would permit an exploration of sustainable development options truly capable of being pursued indefinitely.

\section{Conclusion}

The Brundtland Commission Report of 1987 laid out an inherently unsustainable path for realizing sustainable development when it endorsed the idea of 'sustainable economic growth' as an essential prerequisite for sustainable development. Unfortunately, the rationales used to support the idea of 'sustainable economic growth' in that Report have continued to represent dominant, mainstream thinking within the sustainable-development movement over time. As a direct result, the movement has continued to demonstrate a decidedly pro-growth bias both in sustainable-development publications and initiatives. Similarly, the sustainable-cities movement, with its recent affiliation with the 'smart-growth' movement in the United States, has started to endorse the idea of a 'sustainable urban growth' option for new sustainability initiatives within urban centres. This ongoing, pro-growth orientation within the sustainable-development and sustainable-cities movements has diverted attention from the pressing need to acknowledge the intrinsically unsustainable nature of material growth in economic and urban terms. It has also served to impede meaningful consideration of actual 'development' options needed to realize sustainable development and sustainable cities. With mounting evidence of 
existent ecological limits to growth, the time has come to abandon the vacuous oxymoron of 'sustainable growth' and undertake consideration and implementation of truly sustainable development paths.

\section{References}

[1] Leisinger, K.M., Sustainable development at the turn of the century: perceptions and outlook. Sustainable Development, 1(1), pp. 73-98, 1998.

[2] Holden, E. \& Linnerud, K., The sustainable development area: satisfying basic needs and safeguarding ecological sustainability. Sustainable Development 15(3), pp. 174-187, 2007.

[3] World Commission on Environment and Development, Our Common Future, Oxford University Press: Oxford, 1987.

[4] Boron, S. \& Murray, K., Bridging the unsustainability gap: a framework for sustainable development. Sustainable Development 12(2), pp. 65-73, 2004.

[5] Hediger W., Towards an ecological economics of sustainable development. Sustainable Development 5(3), pp. 101-109, 1997.

[6] Giddings, B., Hopwood, B. \& O’Brien, G., Environment, economy and society: fitting them together into sustainable development. Sustainable Development 10(4), pp. 187-196, 2002.

[7] Lamberton, G., Sustainable sufficiency - an internally consistent version of sustainability. Sustainable Development 13(1), pp. 53-68, 2005.

[8] Pell, D.J., The local management of planet earth: towards a 'major shift' of paradigm. Sustainable Development 4(3), pp. 138-148, 1996.

[9] Carvalho, G.O., Sustainable development: is it achievable within the existing international political economy context? Sustainable Development 9(2), pp. 61-73, 2001.

[10] Giddings, B., Hopwood, B. \& O’Brien, G., Environment, economy and society: fitting them together into sustainable development. Sustainable Development 10(4) pp. 187-196, 2002.

[11] Bürgenmeier, B., Globalization versus sustainable development: a question of the common good. International Journal of Sustainable Development 2(4), pp. 449-457, 1999.

[12] Franks, T.R., Managing sustainable development: definitions, paradigms, and dimensions. Sustainable Development 4(2), 53-60, 1996.

[13] Hopwood, B., Mellor, M. \& O’Brien, G., Sustainable development: mapping different approaches. Sustainable Development 13(1), pp. 38-52, 2005.

[14] Luke, T.W., Neither sustainable nor development: reconsidering sustainability in development. Sustainable Development 13(4), pp. 228238, 2005.

[15] Wheeler, S., Planning for metropolitan sustainability. Journal of Planning Education and Research 20(3), pp. 133-145, 2000.

[16] Wheeler, S.M. \& Beatley, T., (eds). The Sustainable Urban Development Reader, Routledge: London, 2004.

[17] Zovanyi, G., Growth Management for a Sustainable Future: Ecological Sustainability as the New Growth Management Focus for the $21^{\text {st }}$ Century, Praeger: Westport, Connecticut and London, 1998. 
[18] DeGrove, J. \& Metzger, P., (eds). Balanced Growth: A Planning Guide for Local Government, International City Management Association: Washington, D.C., 1991.

[19] Kaiser, E., Godschalk, D. \& Chapin, F., Urban Land Use Planning, University of Illinois Press: Urbana, Illinois, 1995.

[20] Nelson, A., Duncan, J., Mullen, C. \& Bishop, K., Growth Management Principles and Practices, Planners Press: Chicago, Illinois, 1995.

[21] Zovanyi, G., The role of initial statewide smart-growth legislation in advancing the tenets of smart growth. The Urban Lawyer 39(2), pp. 371414, 2007.

[22] Burchell, R., Listokin, D. \& Galley, C., Smart growth: more than a ghost of urban policy past, less than a bold new horizon. Housing Policy Debate 11(2), pp. 821-879, 2000.

[23] Daly, H.E., Steady State Economics: Second Edition with New Essays. Island Press: Washington, D.C., 1991.

[24] Meadows, D.H., Meadows, D.L., Randers, J. \& Behrens, W.W. III., The Limits to Growth. Potomac: New York, 1972.

[25] Cipolla, C., The Economic History of World Population. $7^{\text {th }}$ edition, Penguin Books: New York, 1978.

[26] Brown, L.R., Eco-Economy: Building an Economy for the Earth. $\mathrm{W} \cdot \mathrm{W} \cdot$ Norton \& Company: New York, 2001.

[27] World Resources Institute, World Resources: A Guide to the Global Environment-The Urban Environment. Oxford University Press: New York, 1996.

[28] Lubchenco, J.A., Olson, A.M., Brubaker, L.B., Carpenter, S.R., Holland, M.M., Hubbell, S.P., Levin, S.A., MacMahon, J.A., Matson, A.A., Melillo, J.M., Mooney, H.A., Peterson, C.H., Pulliam, H.R., Real, L.A., Regal, P.J. \& Risser, P.G., The sustainable biosphere initiative: an ecological research agenda-A report from the Ecological Society of America. Ecology 72(2), pp. 371-412, 1991.

[29] Wilson, E.O., The Diversity of Life. Harvard University Press: Cambridge, MA, 1992.

[30] Wackernagel, M., Onisto, L., Linares, A.C., Falfán, I.S.L., García, J.M., Guerrero, A.I.S. \& Guerrero, M.G.S., Ecological Footprints of Nations: How Much Nature Do They Use? How Much Nature Do They Have? Commissioned for the Rio+5 Forum, International Council for Local Environmental Initiatives: Toronto, 1997.

[31] Balmford, L., Bruner, A., Cooper, P., Costanza, R., Farber, S., Green, R.E., Jenkins, M., Jefferiss, P., Jassamy, V., Madden, J., Munro, K., Myers, N., Naeem, S., Paavola, J., Rayment, M., Rosendo, S., Roughgarden, J., Trumper, K. \& Turner, R.K., Economic reasons for conserving wild nature. Science 297(5583), pp. 1-8, 2002.

[32] World Wildlife Fund International, Living Planet Report 2004. World Wildlife Fund: Gland, Switzerland, 2004. Online. http://www.npg.org

[33] Millennium Ecosystem Assessment, www.milleniumassessment.com

[34] Intergovernmental Panel on Climate Change, www.ipcc.ch 